ISSN 2080-1653

Dol 10.24917/20801653.334.15

\author{
MALWINA KOBYLAŃSKA \\ KGHM CUPRUM Ltd. Research and Development Centre, Wrocław, Poland \\ MAREK W. LORENC \\ Wroclaw University of Environmental and Life Sciences, Wrocław, Poland
}

\title{
Execution of the Tasks of Geotourism in the Post-Mining Objects and Sites as the Way for Using and Promoting Former Industrial and Mining Facilities
}

\begin{abstract}
Each geotourist venture should be related to the creation of a tourist product from the geological or post-mining object. This preparation to tourist traffic through the adaptation or making the object available to visitors is the primary objective which implies the series of different tasks. These tasks of geotourism, in post-mining objects and sites - the special type of cultural heritage resources, are presented in the paper. Execution of each task was discussed on the basis of different examples of development of post-exploitation sites all over the world, e.g. in Spain, Poland, Germany, England, and Australia. The form and scope of the geotourist tasks execution formed the base for the authors for the assessment of selected development practices, as well as the definition of application guidelines introduced in this paper. All tasks facing geotourism based on former industrial and mining facilities should form a coherent whole, covering the economic (profitability), ecological (neutrality) and socio-cultural aspect (social justice), and thus fit in the concept of sustainable development in tourism. These pillars should be treated equally, because only their reasonable combination has the chance to result in the creation and development of sustainable tourism.
\end{abstract}

Keywords: geotourism; industrial facilities; mining heritage; post-exploitation sites; post-mining objects

Received: 17 April 2019

Accepted: 31 July 2019

Sugerowana cytacja / Suggested citation:

Kobylańska, M., Lorenc, M.W. (2019). Execution of the Tasks of Geotourism in the Post-Mining Objects and Sites as the Way for Using and Promoting Former Industrial and Mining Facilities. Prace Komisji Geografii Przemysłu Polskiego Towarzystwa Geograficznego [Studies of the Industrial Geography Commission of the Polish Geographical Society], 33(4), 241-259. doi: 10.24917/20801653.334.15

\section{INTRODUCTION}

Geotourism, combining nature tourism and cultural tourism, with regard to its complexity (adhesion to both natural and social sciences) and relation to many forms of tourism as specialist, qualified tourism and ecotourism, became a separate form of tourism. Słomka defines geotourism as a section of cognitive tourism focused on experiences in the field of learning about geological objects and processes, as well as experiencing aesthetic experiences in contact with them (Słomka, Kicińska-Świderska, 2004). 
This new scientific discipline (although, opinions are still divided whether it may be called geotourism), associated with inanimate nature resources, is attributed to the applied geology due to the practical use of basic geology research, and due to the limited impact of tourism on the state of natural environment - to the ecotourism (Alexandrowicz, Alexandrowicz, 2002).

Geotourist attraction is represented by geotourist objects, as well as phenomena of this nature i.e. geological processes (e.g. volcanic eruptions). Among geotourist attractions, one can also mention monuments of inanimate nature, didactic paths, geotopes and geoparks. It should be emphasised that the term geotourism attractiveness is both complex and relative due to various psychophysical conditions of tourists and the way of using a given object/area for practising various forms of tourism (Kobylańska, 2014).

The subject of research in geotourism is geological heritage (geoheritage), understood by Hose as the physical qualities of geostands and products based on them created by humans (Hose 2006) and analysis of geodiversity, i.e. variability and mosaic of geological structure, and soils, their systems and processes occurring between them (Davey, 1997). This results in the use by geotourism from natural (geological) heritage and cultural heritage (based on inanimate nature, anthropogenic objects, such as mines and quarries), which includes industrial heritage.

Still, the object of interest of geotourism is always geological sites that can be transformed into a tourism product (more precisely: geotourism product). Therefore, geological or post-mining sites, in the narrow sense, are geotourism sites only when they are prepared for tourism management e.g. through adaptation or/and giving access to. Achievement of this goal, which is primary to undertakings related to geotourism, carries the necessity of execution of many tasks in different dimensions such as, among others, research, organisational and educational one. The goals of the article are to discuss the scope and executive practices for each of the tasks of geotourism in post-mining facilities adapted for tourism purposes, as well as the indication of implementation guidelines in this kind of undertakings.

\section{GEOTOURISM IN POST-MINING SITES AND POST-EXTRACTION AREAS}

Geotourism in the post-mining sites is an interdisciplinary domain of tourism which rapid development in many European countries within the last several years is attributed to, among others, post-industrial transformation of post-mining areas and an expanding area of interest of an average tourist. Some researchers emphasise that tourism in post-mining sites, joining geological and industrial qualities together, in the case of predominance of industrial features, should be classified as post-industrial tourism (not geotourism), however, this statement is recently becoming less and less popular since these two forms are coexistent, complementary and overlapping and, in practice, a tourist who participates in e.g. a tourism event is a participant of many forms of tourism at once (Różycki, 2010).

Among others, the following notions are essentially equal to the notions of geotourism based on relics of mining activities developed for tourism purposes:

- cultural tourism in post-industrial/post-mining sites,

- post-mining tourism, tourism within post-mining areas,

- tourism within post-industrial areas, 
- industrial tourism - practiced in order to get to know qualities of certain industrial activity; sites are visited during the working hours of a plant, e.g. mining or foundry facility,

- post-industrial tourism - practiced to get to know the qualities of industrial heritage (historic industrial buildings and engineering); and sites are visited after the shutting down of a mining or processing plant,

- mining geotourism/geotourism in post-mining sites,

- industrial/mining heritage tourism.

The fact that the above-mentioned notions also refer to sustainable tourism, that is, one connected with the idea of sustainable development, is worth emphasising here. Some authors consider industrial tourism as a form of education and recreation organised within the areas of present or past economic activity. Still, in recent years, there has been a clear distinction visible between the notion of post-industrial tourism and industrial tourism, that is, one focused on the activities of currently operating industrial plants. However, one should emphasise that an operating mining facility may be also a successful geotourism site where a tourist can observe mining and/or processing actions as, for instance, in Kłodawa Salt Mine in Poland.

Two basic directions of destination for a geotourist are historic mines which constitute a testimony to history of mining works within a certain area and give access to underground environment, and surface engineering objects of historic value, as well as open-pit mining facilities (including quarries). The development of the latter for tourism purposes should be focused on displaying the post-mining landscape which often is of historic value itself.

The list of objects of tourist's interest in post-mining sites (developed and undeveloped ones) can be found in Table 1. Landscape values related to biodiversity, as well as historical and geological values are the basis of this interest and constitute the originality of a geotourist object. Often, however, a geotourist is not so much interested in geology as in mining or metallurgy, and that gives a utilitarian dimension, e.g. in the context of the use of mineral resources, and a humanistic dimension, e.g. in the context of the history of engineering, to geological issues (Zagożdżon, Zagożdżon, 2013).

Table 1. Geotourists' areas of interest in post-mining sites

\begin{tabular}{|l|l|l|}
\hline $\begin{array}{l}\text { Lalues } \\
\text { of a site } \\
\text { of a site }\end{array}$ & \multicolumn{1}{|c|}{ Above-ground } & \multicolumn{1}{|c|}{ Underground } \\
\hline Landscape & $\begin{array}{l}\text { Open cast, exploratory heading, post- } \\
\text {-excavation water bodies, post-mining } \\
\text { landscape and scenery, flora and fauna } \\
\text { connected with recovery of nature }\end{array}$ & $\begin{array}{l}\text { Fauna and flora connected with recovery } \\
\text { of nature, scenery of underground } \\
\text { excavations }\end{array}$ \\
\hline Geological & $\begin{array}{l}\text { Geodiversity - geological, hydrogeological, } \\
\text { lithological and geomorphological } \\
\text { processes and phenomena, geosites, } \\
\text { minerals, knowledge of geology }\end{array}$ & $\begin{array}{l}\text { Geodiversity - geological, hydrogeological } \\
\text { and lithological processes and } \\
\text { phenomena, mineralisation signs in } \\
\text { underground excavations, geosites, } \\
\text { minerals, knowledge of geology }\end{array}$ \\
\hline Historic & $\begin{array}{l}\text { Movable and immovable mining } \\
\text { engineering objects of historic value, } \\
\text { knowledge of the history of a site, } \\
\text { museum exhibits, technology in opencast } \\
\text { mining }\end{array}$ & $\begin{array}{l}\text { Movable and immovable mining } \\
\text { engineering objects of historic value, } \\
\text { knowledge of the history of a site, } \\
\text { museum exhibits, technology in } \\
\text { underground mining }\end{array}$ \\
\hline
\end{tabular}




\begin{tabular}{|l|l|l|}
\hline \multicolumn{1}{|l|}{} & $\begin{array}{l}\text { Research results, anthropogenic } \\
\text { landscape, geointerpretation, knowledge } \\
\text { of a site, method of conveying knowledge } \\
\text { of a site, diversity and features of } \\
\text { resources }\end{array}$ & $\begin{array}{l}\text { Research results, geointerpretation, } \\
\text { knowledge of a site, method of conveying } \\
\text { knowledge of a site, diversity and } \\
\text { features of resources, natural threats }\end{array}$ \\
\hline Recreational & $\begin{array}{l}\text { Events connected with a site, attractions } \\
\text { which are not connected with mining, } \\
\text { method of conveying knowledge of a site, } \\
\text { adventure, fitness }\end{array}$ & $\begin{array}{l}\text { Events connected with a site, miners' } \\
\text { working conditions, attractions which are } \\
\text { not connected with mining, method of } \\
\text { conveying knowledge of a site, adventure, } \\
\text { fitness }\end{array}$ \\
\hline
\end{tabular}

Source: authors' own work based on Kobylańska (2014)

\section{TASKS OF GEOTOURISM PRODUCT}

The primary objective of every geotourism undertaking, that is creation of a tourism product from a geological site, results in the necessity of executing a number of tasks. The most important tasks are as follows:

- documentation,

- educational (teaching),

- promotion,

- research and development,

- protection,

- designing,

- organisational,

- training.

The mentioned tasks were described below with reference to the processes of development of a geotourism product on the basis of post-mining sites and the management of this product. The tasks were discussed and selected examples were provided. Additionally, some practical solutions were assessed.

\section{DOCUMENTATION AND EDUCATION IN POST-MINING SITES}

The documentation task of geotourism consists of documenting and developing information concerning a certain geological or mining site. Usually, activities in this scope are initiated by geological discoveries and discoveries of former mining sites, exploratory research, archive queries or the very beginning of creating a geotourism showplace in a certain place and a need of more information on the place, for instance, in a historic aspect. Documentation of knowledge of a certain post-mining site or area can be focused on, among others, gathering information and creating databases concerning former mines and places of historic excavation, including not only technological (mining technology), historic and geological issues but also natural and social ones (life, traditions and customs of former miners). The execution of the documentation task can take place for one unit, e.g. for a certain mining facility's purposes, and in a wider range - for a local area (region, the world), e.g. Nord-Pas de Calais post-mining basin in France, or on the basis of a theme, e.g. "Historic Quarries" database in selected European countries which was established within the frameworks of the EU "CULTURE 2007-2013" programme.

An example of an all-embracing approach to execution of the documentation task in the context of mining geotourism is Centro de Interpretación del Paisaje Minero in 
Linares (the northern part of Andalusia) in Spain. The Centre of Mining Interpretation was established in 2006 and it has been successfully joining a traditional approach to museology with innovative solutions within the scope of education and conveying knowledge of mining in its broad sense ever since (Photo 1).

The institution behind the idea was Colectivo Proyecto Arrayanes, the association established in 1998, which aims at protecting and preserving the mining heritage of Linares-La Carolina region for the future generations. What is more, among the considerable achievements of Colectivo Proyecto Arrayanes, one should mention the preservation of Roman mining remnants in Palazuelos and La Fernandina (Peréz Sánchez, Lorenc, 2008) and publication of the history of the local mining together with a catalogue of all so far recognised sites of mining heritage (Contreras Cortés, Dueñas Molina, 2010), which shows special diligence in documenting the history of the region. Each site is described by a registry card that includes different elements (pumping engine house, Cornish house, winding engine house, chimney, water reservoir, shaft, head frame, ore dressing, railway station, furnaces, etc.), geographical situation, a brief description of the history, some photographs (ancients and news), state of preservation, singularity and bibliographic references. Till now, more than 2,000 remnants (elements) had been included into the 520 registry cards in the full project (Campos López et al., 2014). One should add here that an important element of documenting knowledge of a certain mining area, also used by Colectivo, is finding people who have first-hand information, that is, the workers of a particular mining facility, and obtaining verbal message recordings.

The educational (teaching) task of geotourism concerns geoeducation, that is, education within the scope of the Earth and mining. The task naturally results from the documentation task and it entails providing the visitors with information on a particular

Photo 1. The inside of Centro de Interpretacion del Paisaje Minero in Linares, Spain

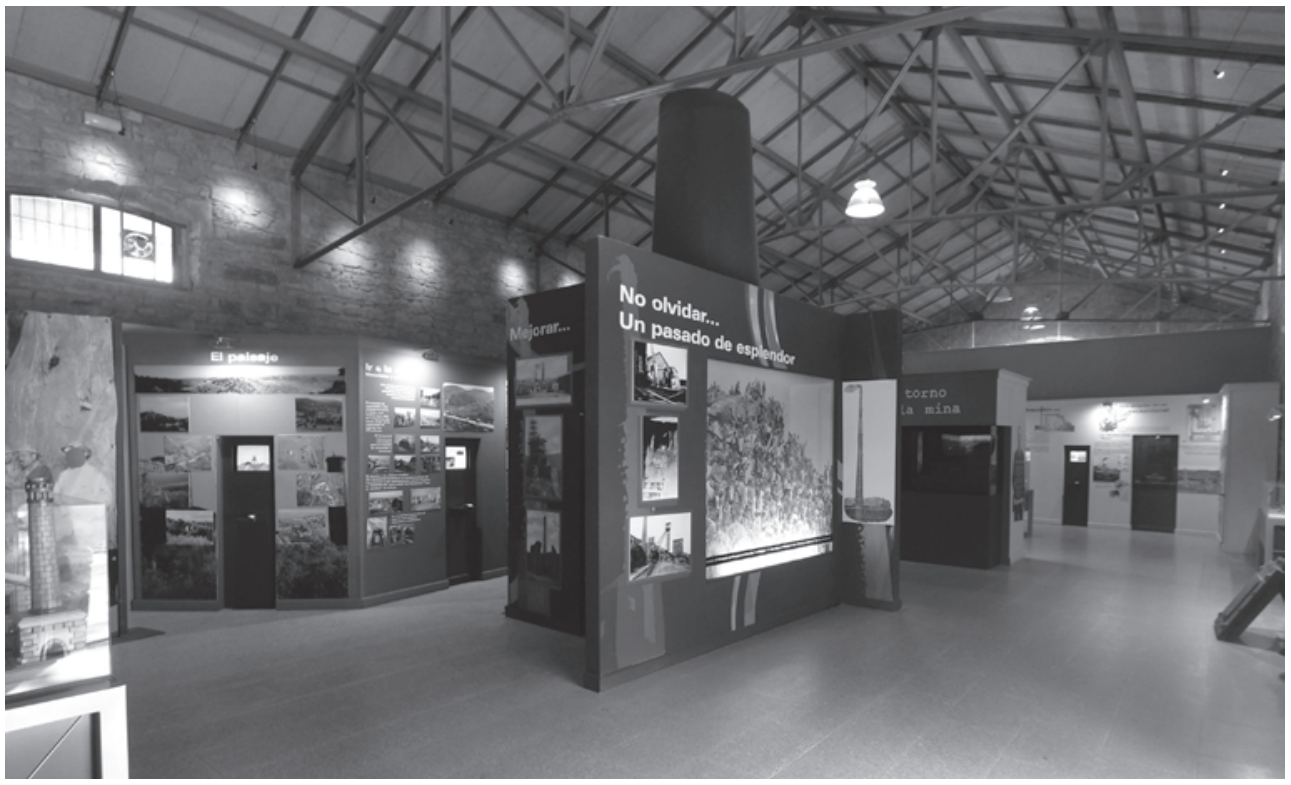

Source: M.W. Lorenc 
site and region. In the case of geological sites, geotopes (geological sites, geosites) are of special educational significance - these are features of inanimate nature providing information on the structure of lithosphere and the Earth's development, which are valuable in the context of geological history of a particular place. The possibility of observing a geotope in the conditions of its occurrence, which documents e.g. geological processes of a particular region, is important here.

The GeoTrails - illustrated educational and geotourism boards, which provide professional and clear information on geological attractions of a particular place - are tools for informing tourists of a site and its historic, geological, cultural values, etc., commonly used all over the world (Figure 1).

In the case of bigger post-mining sites or complexes, educational values are especially provided by museums with a mining theme and former mining facilities - mines

Figure 1. Information board for "Fryderyk Wilhelm" adit, one of the sites on "Following the Traces of Former Ore Mining" in Mirsk Commune, Poland

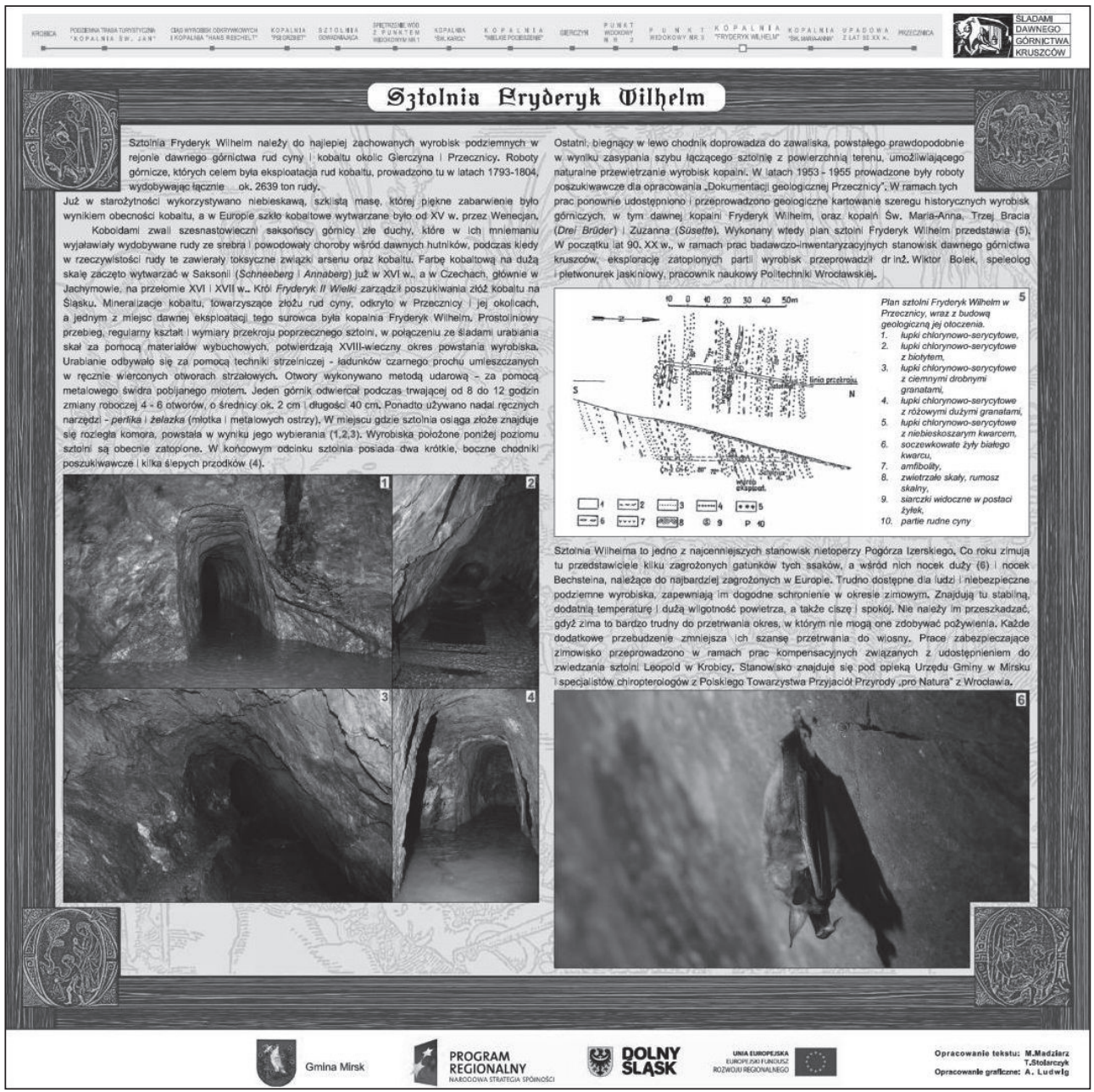

Source: compilation by M. Madziarz, T. Stolarczyk 
adapted for tourism. A model example of an undertaking focused on educational functions is Regional Eco-museum of Mining of Germanasca Valley, located in Piedmont Region (Turin Province) in Italy. The museum was established upon the request of the local community in 2003 and it shows the visitors the local, Alpine landscape, the culture of local community and lifestyle of miners. Talc mining in this region has over 200-year history, which has had a great influence on the culture and lifestyle of residents of local valleys.

This museum, apart from its typical museum activity, that is exhibition, also actively contributes to education by offering several quality programmes. One of those is ScopriMiniera programme ("Discover the Mine"), which is a tourism and culture product specialised in promoting talc mining. It offers an underground route within Paola mine where the methods of extraction of talc, which is found in a form of veins among hard metamorphic rocks, are presented and explained. The route is approximately $4 \mathrm{~km}$ long. The product dedicated to getting to know the regional geology is ScopriAlpi route ("Discover the Alps"), which provides explanation for tectonic processes resulting in the elevation of the Alps due to the collision of the African and European continents. The underground route shows headings of Giana mine and equipment for excavation and transport of the excavated material. The educational programme is supported by high-tech and well-programmed audiovisual equipment. Giana mine is located below Paola mine, and thanks to the underground connection of passages of both mines, there is a possibility of enjoying both routes (Figure 2).

An important achievement of the Eco-museum is the fact that its educational division enables one to organise laboratory classes and theme trips along the underground passages for primary and high school youth. These classes include information

Figure 2. The plan of tour route for Giana and Paola mines in the Regional Eco-museum of Mining of Germanasca Valley, Italy

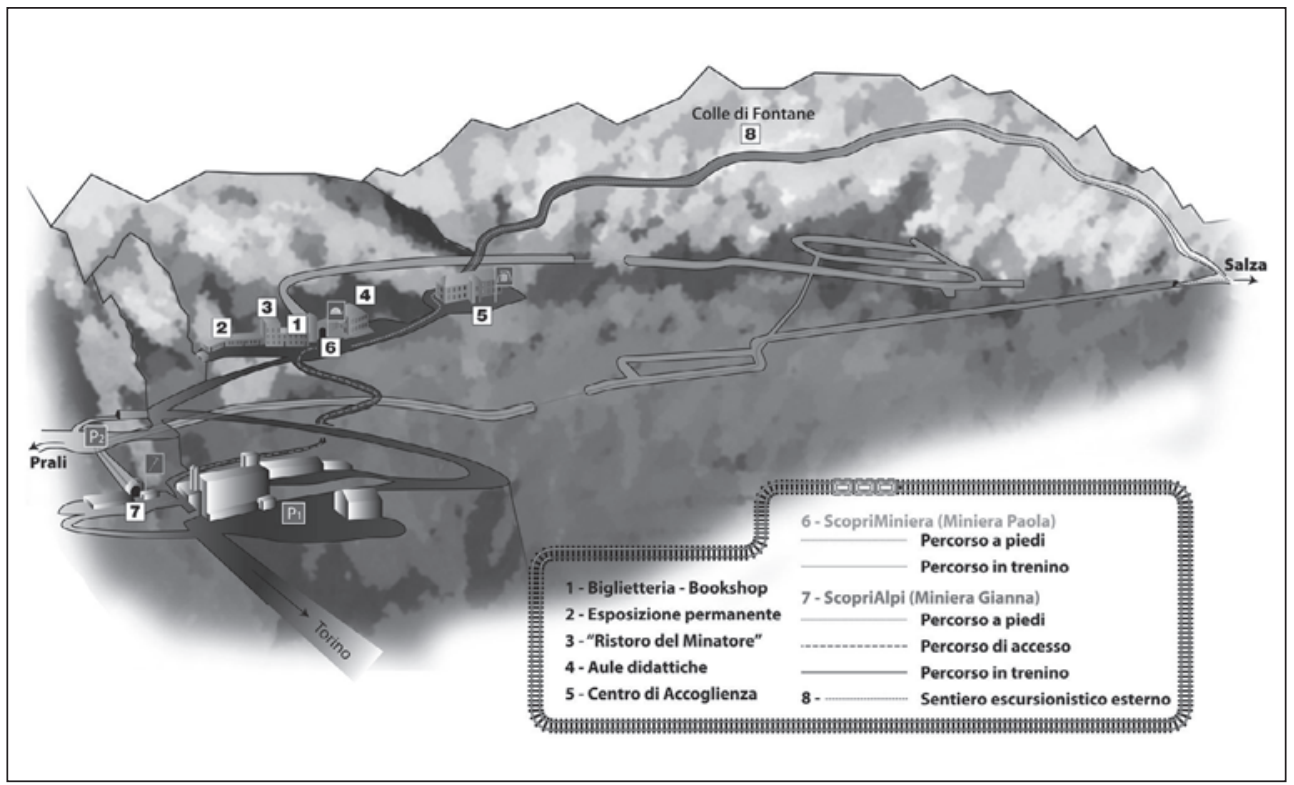

Source: www.scopriminiera.it 
concerning culture, geology and natural environment science. An extremely important and valued aid in putting these classes into practice are professionally edited thematic textbooks and exercise books for students of particular level of education, officially approved by the Italian Ministry of Education. Thanks to these actions, the Eco-museum enables the tourists to get to know an interesting mining facility as well as talc excavation and processing technologies. Simultaneously, it educates school-age youth effectively, conveying knowledge of economic significance of the area, its history, culture, and customs of the mining community thanks to interesting classes.

According to the authors, good practices within education concerning geology and mining should be characterised by integrity and end-to-end approach of the message, as well as its adjustment to geotourists' needs. The adjustment may concern age, concentration abilities, and interests of the particular visiting groups, e.g. school-age groups enjoy education joined with entertainment (edutainment) the most (Photo 2). What is more, different types of educational and natural programmes dedicated mainly for children and youth are practiced in certain tourist destinations.

Another example of realisation of the education function within the scope of knowledge of mining at a large scale is the National Coal Mining Museum for England located near Wakefield in the western part of Yorkshire (Photo 3). The mine had been operating up till 1985, and the museum was opened in 1988. Apart from the exhibition function, the museum's mission is educating the society within the scope of mining history through presenting changes and evolution of methods of mining and used machines and equipment. A separate branch is rapidly developed mining and industrial archaeology. The constantly expanding collection of mining (including mining culture) heritage exhibits preserves still living knowledge of this industry.

Photo 2. An example of adapting post-mining site to the needs of the youngest visitors - the role of a guide is performed by "Blue Rat"; former foundry "Henrichshütte” in Hattingen, Germany

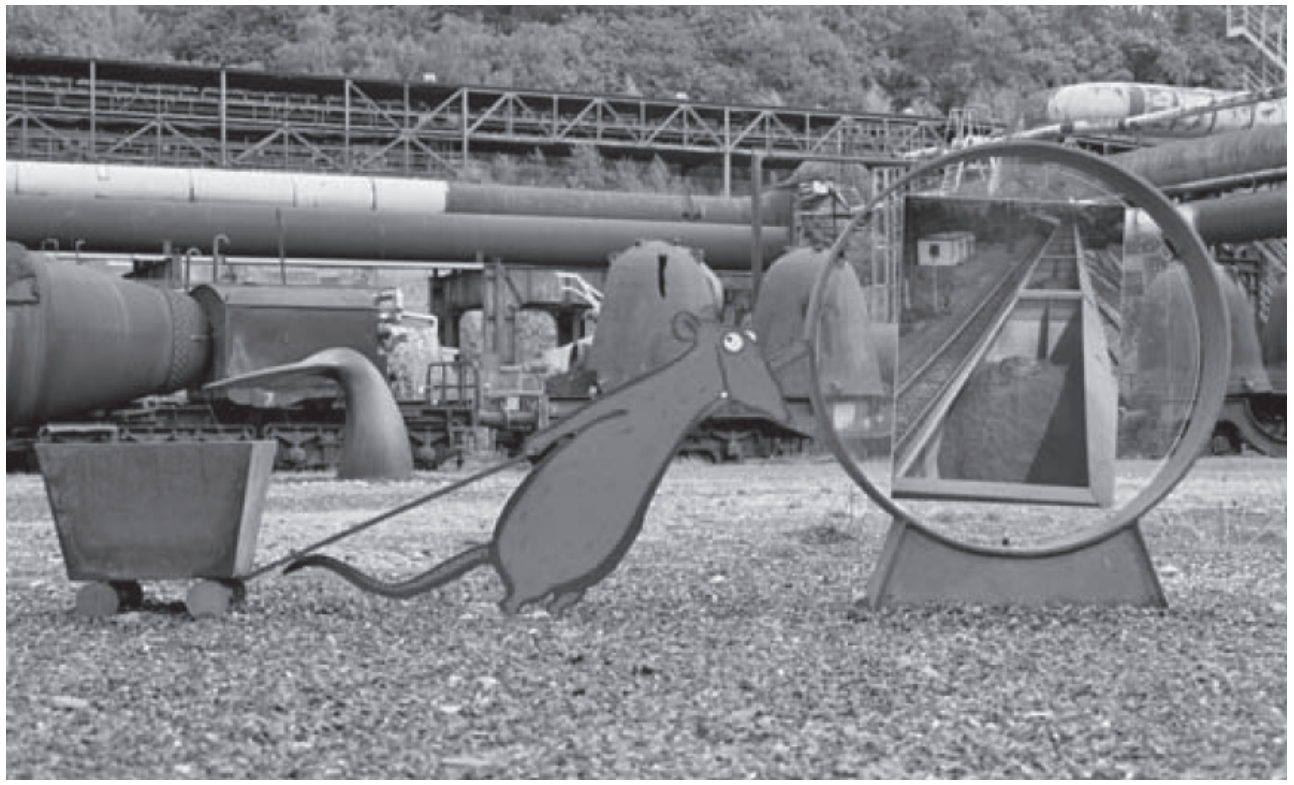

Source: W.J. Affelt 
Photo 3. Entrance to National Coal Mining Museum for England, Caphouse, Wales

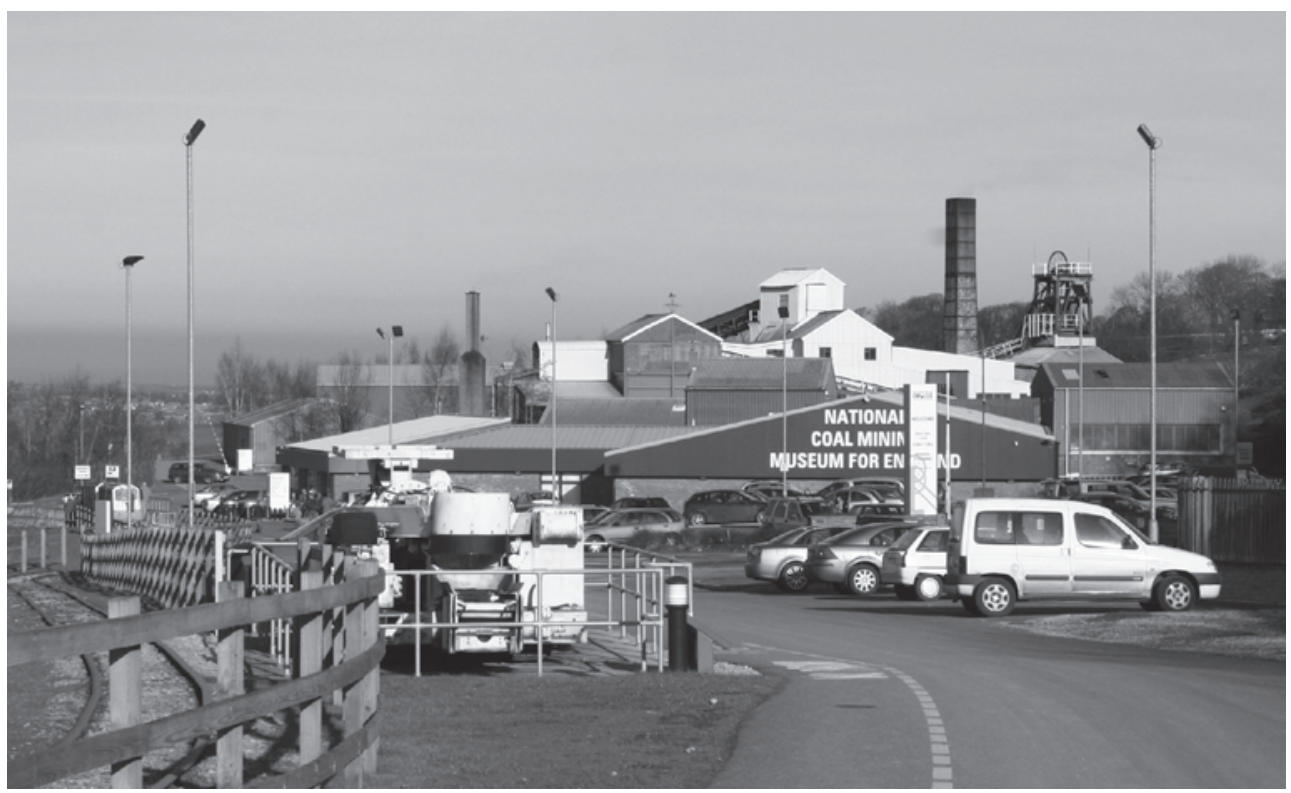

Source: M.W. Lorenc

One should bear in mind that, in post-mining tourism, the objects of geotourists' interest are especially post-mining sites and areas, and these qualities should be dominating in the process of their development for tourism purposes. This shows the validity of creating "living mining museums" and geotourism attractions in situ, that is, in places originally used as mining facilities. This also results in a number of recommendation for a future investor, and the main ones are as follows:

- care of emphasising the mining heritage of a particular place through preserving, protecting and exhibiting its elements,

- the least interference into the state of existing objects (e.g. workings) possible, which enables one to preserve the historic value of the relics of mining activity and may be used in promoting a tourist attraction (maintaining safety of the visitors),

- avoiding degradation of historic cultural landscapes through disturbing the scenery with random architectural structures and elements of tourism-related infrastructure,

- care of increasing social awareness of the visitors concerning legacy and craft of mining, as well as its significance in connection to the civilisation development, e.g. through interesting and properly conveyed information (e.g. information provided by the guide, website, educational materials).

The promoting task of geotourism is related to presenting and promoting geological and mining heritage, and it is often interrelated with the educational task, that is, conveying information via different media. The uncommon, original solutions, skilfully taking advantage of the public space, deserve special attention; these are, for instance, benches located in Paseo de la Virgen de Linarejos in the above-mentioned Linares, Spain (Photo 4). First "Seville" style benches were placed there about 80 years ago. In 2009 , the avenue was renovated and decorated with new benches immortalising the 
industrial past of the city. Almost each bench has got different pattern of the ceramics and reproductions of 19 th century photographs on backrests reminding the visitors of the industrial history of the city (Photo 5).

What is more, the aforementioned tasks of geotourism (documentation, education, promotion) are related to the research and development task. This is composed of different kinds of research within the site and its surroundings (e.g. observations, experiments, statistical methods, simulations), as well as interpretation and development of tools and methods of research character. The so-called geointerpretation plays a very important role here, and it is defined as interpreting (processing) of knowledge within the scope of geological sciences and mining in a way that this knowledge (academic language) is understandable and attractive for tourists regardless of their age,

Photo 4. One of the benches presenting the history of mining of Paseo de la Virgen de Linarejos in Linares, Spain

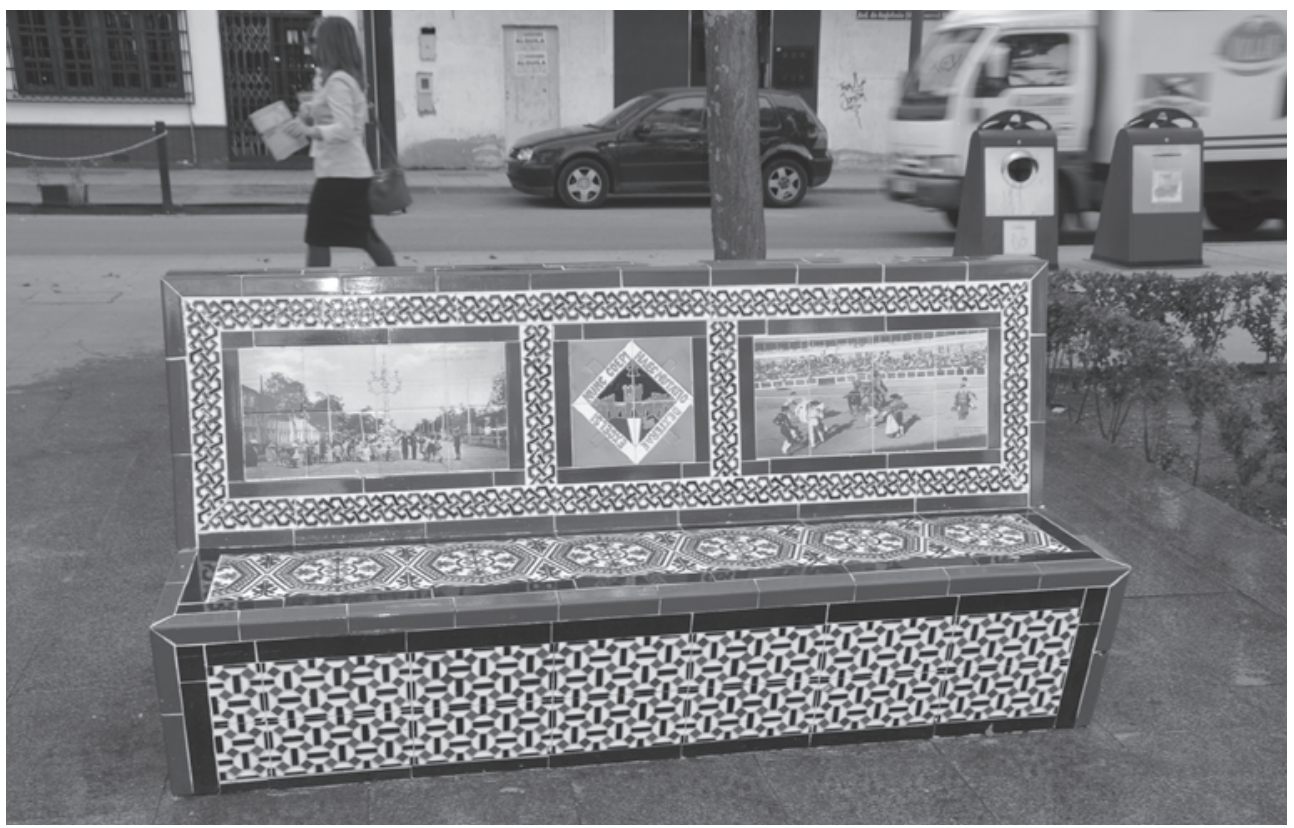

Source: M. Kobylańska

Photo 5. Pozo Ancho shaft in the original photograph from 1908 and the ceramic backrest created on this basis in one of the benches in Paseo de la Virgen de Linarejos in Linares, Spain

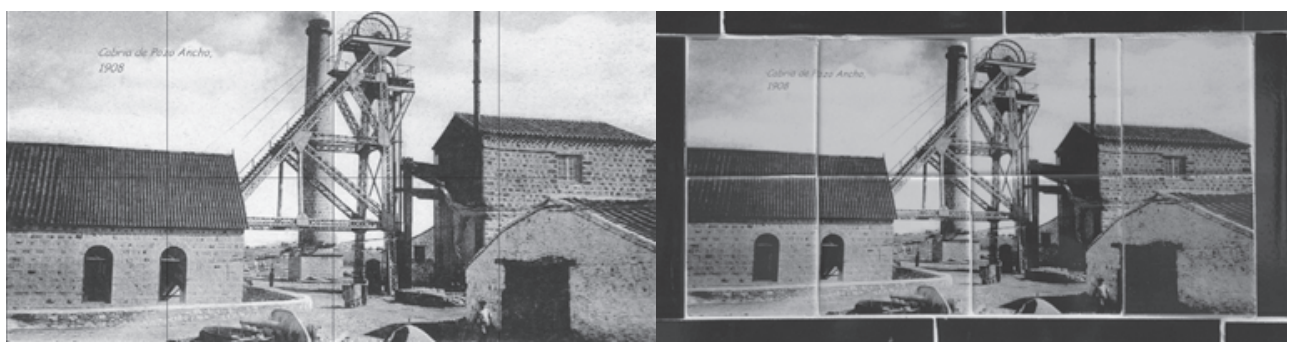

Source: Colectivo Proyecto Arrayanes collection (left), M.W. Lorenc (right) 
level of education, obtained knowledge, etc. The original character of geointerpretation, apart from services rendered to visitors, is often the biggest attraction for tourists (Kobylańska 2014).

\section{MINING HERITAGE PROJECT AS A KEY TASK OF GEOTOURISM}

The protection task of geotourism deserves special attention as it results from the need of protecting and preserving geotourism, including post-mining sites. This includes conservation and restoration works, as well as present use of these site, led by tourism purposes. The specialists of the subject have been trying to answer the question where the limit of using geological sites and relics of the past for the tourism purposes is when one wants to execute this task without threatening or destroying them.

Therefore, making geological sites and historic buildings accessible to tourists must be rational and sustainable; otherwise, this creates a threat of destruction of the particular components of material and immaterial cultural heritage (Zeidler 2009). Mass tourism, that is, mass entry of tourists into a particular area, constitutes a considerable threat here as it is accompanied by many negative phenomena, especially, degradation of natural environment (Kaspar 1991). Casagrandi and Rinaldi believe that formulating strategies and recommendations whose implementation would guarantee tourism activity within the particular area without any influence on the environment is impossible (Casagrandi, Rinaldi 2002). Transforming mining historic sites in a way that they satisfy visitors' needs within the frameworks of mass tourism is often connected with the desire of making a profit quickly or getting the return on the investment.

A similar situation concerns sites and areas of inanimate nature - tourism intensification constitutes a real threat to these. Therefore, the protection task of geotourism is also connected with regulations concerning tourism intensity and service conditions within the particular area. In the case of a threat to historic objects of cultural or natural heritage, the most extreme situation may be their complete separation from external factors. An interesting example here is "Crystal Caves" nature reserve in Wieliczka in Poland - it is an underground geological site which is globally unique with regard to accumulation of halite crystals of considerable dimensions (Photo 6) and forms of salt karst; however, completely excluded from tourism. "Crystal Caves" were accessible to tourists for a long time, namely for about 35 years. In 2000, the Caves obtained a status of an underground inanimate nature reserve.

In spite of the above, the practice shows that the protection of the post-mining object itself may be insufficient without analysing the profitability of the project and ideas for its management, as was the case of the Historic Iron Ore Mine "Szczekaczka" in Brzeziny near Czestochowa, Poland. This original facility was open for visitors for a few years, and then closed in 1983 due to the excessive cost of pumping underground waters (Czwartyńska, 2008). The Museum of Mining Industry with some of its monuments is currently located in underground corridors, hollowed out in the years 1974-1976 in the Staszic Park in Czestochowa.

Obviously, in connection to geotourism undertakings based on mining heritage sites, the protection of people visiting the sites is of key importance. Within the process of adapting underground passages to organised tourism, particular attention should be paid to the evaluation of the state of rock mass and its protection with providing safety to tourists in mind - the main threats are rock slides, goafs, lack of oxygen, water and 
Photo 6. Halite crystals in "Crystal Caves" in Wieliczka, Poland

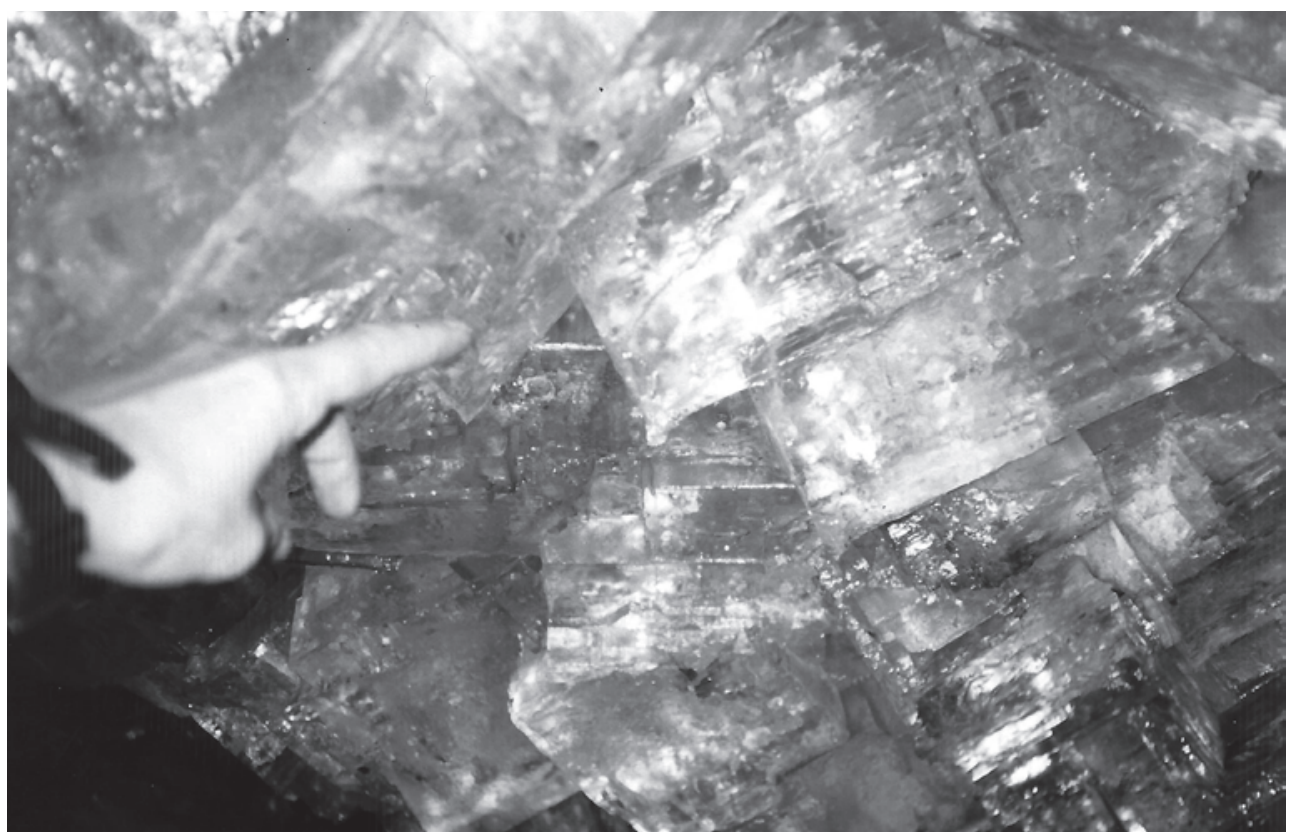

Source: M.W. Lorenc

gas threats. Within the post-exploitation areas, special threats are imposed by subsidence created as a result of collapsing of underground passages (post-mining voids). For the surface sites or underground sites connected with the surface (shafts), the form and scope of protection are different, e.g. these are improvement of the structure's stability or grated shaft inlets (Photo 7); however, the safety of geotourists is always a priority with simultaneous (but not colliding with safety conditions) preservation of historic qualities of a post-mining facility.

Among good practices of providing safety to tourists in post-mining sites, one can find using easily noticeable warning signs (Photo 8), which are especially important within the areas of former exploitation which are not included in an all-embracing programme of regeneration or adaptation for tourism (designated routes, guided sightseeing). In the case of different sites with regard to the level of protection on the geotourist route, defining the protection zone determining tourists' access to the site seems to be justified - e.g. high level of protection means access only for a group of up to 10 people, with a guide, one day a week.

Long-term planning concerning future actions connected with (currently operating) post-mining site should be related to the protection of underground passages with exhibiting their geological or historic qualities during or after exploitation of a certain deposit area in mind. This may be of special significance in the context of creating a geotourism product, and also in the case of re-excavation in the areas subject to exploitation in the past. The protection of historic sites of industrial infrastructure, machines and tools documenting the development of mining technology, objects interesting with regard to their architecture, as well as, relics of material (historic preservation officer's opinion is recommended) and immaterial culture are of equal importance. 
Photo 7. Remnants of San Vicente mine - in the foreground, there is the protected mining shaft - Linares-La Carolina mining district, Spain

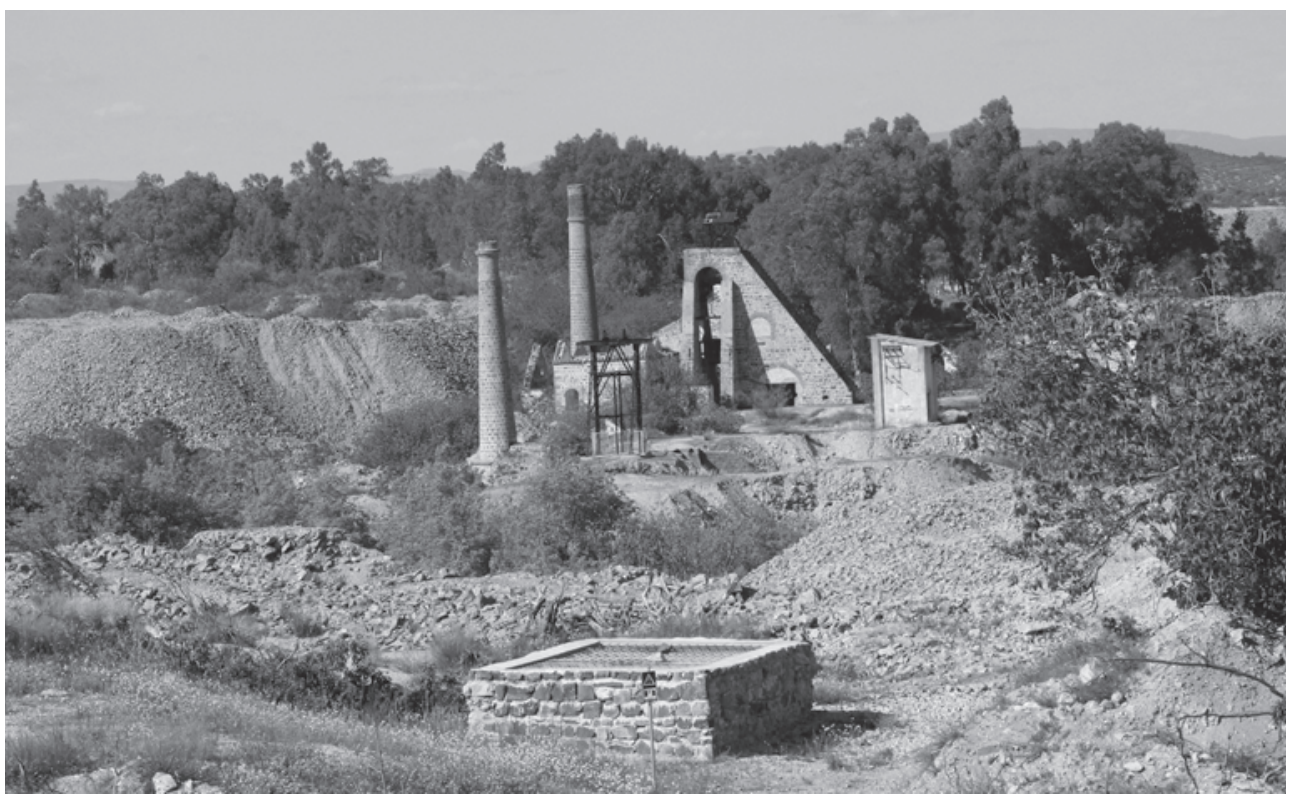

Source: M.W. Lorenc

Photo 8. Classification of threats adopted by Colectivo Proyecto Arrayanes (warning signs) for the purposes of visitors of the remnants of lead mines in Linares-La Carolina post-mining region, Spain

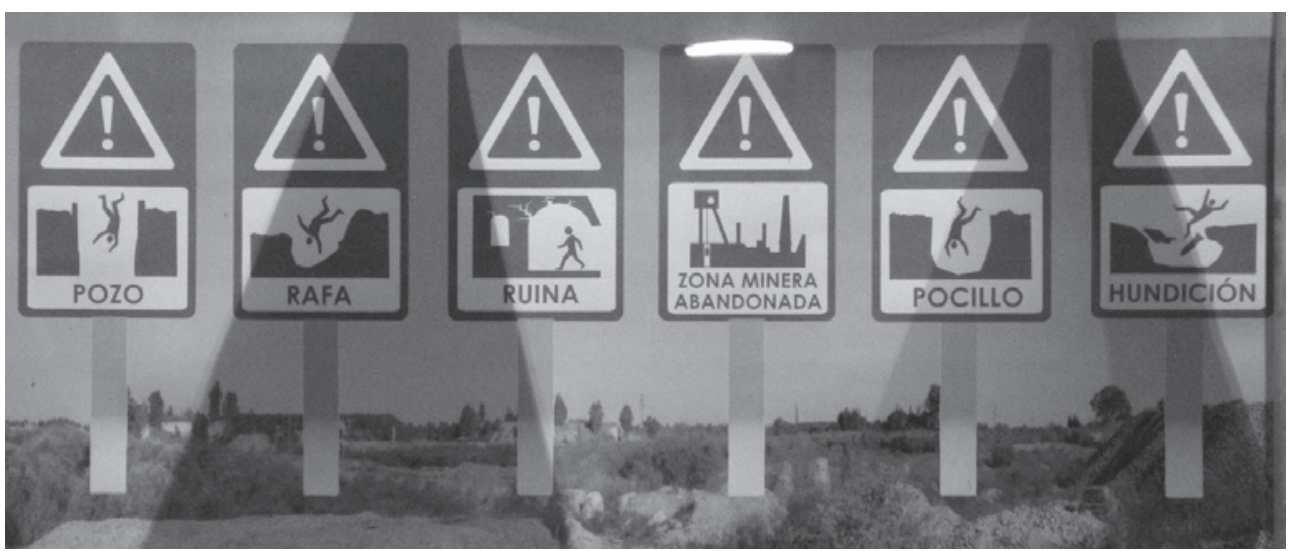

Source: M.W. Lorenc

\section{DESIGNING GEOTOURISM ATTRACTIONS AND TOURISM ORGANISATION}

The designing task of geotourism entails proper preparation of geological and post-mining sites in order to adapt them for tourism purposes, with meeting appropriate technical, economic, legal, environmental, spatial and social requirements. This task is strictly connected with functions the sites/areas will perform in the future. Among the 
most common ones, one may mention adaptations of post-mining sites for the following purposes: scientific and educational, recreational, cultural, sports, economic and environmental. Among many interesting and innovative executions in the context of adaptation projects, one can find EDEN project - a regeneration undertaking which resulted in the establishment of extensive botanical gardens in Bodelva in the southwestern part of the Great Britain in a 160-year-old working after clay excavation. The complex resembles huge soap bubbles and it attracts over one million tourists annually (Photo 9). What is important, the stage of the site's use skilfully joins environmental, educational and cultural aspects together (Baczyńska, Lorenc, 2012; Jawecki et al., 2013; Tokarczyk-Dorociak et al., 2015).

Already at the designing stage, the adaptation of post-mining sites for tourism purposes is an undertaking of a special nature, and gaining a competitive advantage by a certain project should be treated as a separate investment of specific and individual conditions of execution. Bearing the nature of regeneration actions in mind, realised in connection to a post-mining area (the scope of adaptation), one can distinguish three main models of area redevelopments serving for:

- tourism exploitation of sites of high historic qualities (maintaining the function they have performed),

- adaptation of post-mining area to performing new functions - solely industrial or industrial joined with other functions, e.g. educational, recreational, etc. (with great, medium or small connection to the former industrial character of the area),

- liquidation of post-mining legacy and adaptation of the area to perform completely new functions (no connection to the former industrial character).

Photo 9. EDEN Botanical Gardens in Bodelva, England

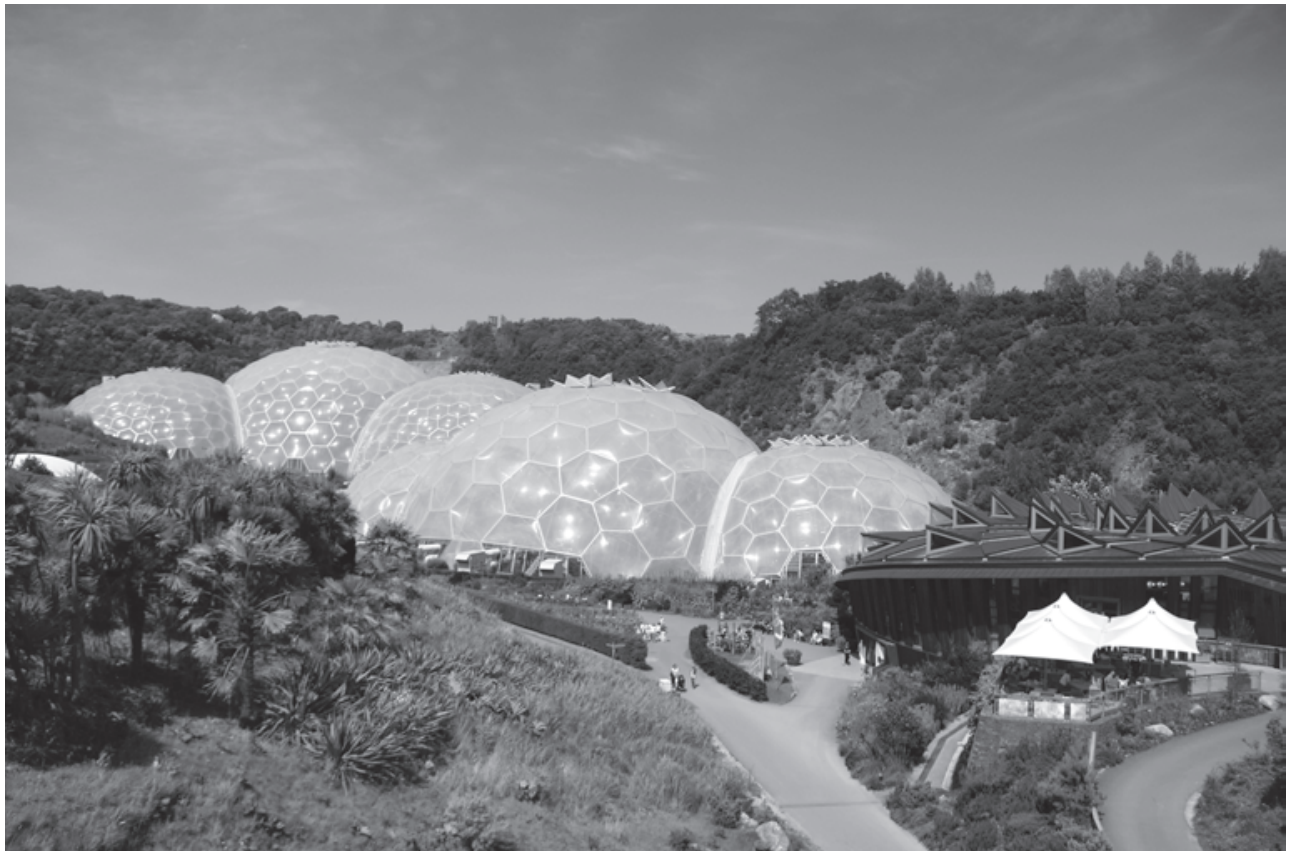

Source: M.W. Lorenc 
An example of an interesting adaptation of post-mining sites with no connection to their former purpose (despite the continuous exploitation in the region) is "Old Timers Mine Coober Pedy" museum in Australia. This was established in a place where opal has been extracted since 1915 and it is still the basic source of the most valuable varieties of these gemstones in the world. An interesting museum of opal was established here in 1987 in one of the mines together with underground public utility facilities and apartments used till the 1960s (Photo 10). Coober Pedy also offers apartments in the former passages and this site has been awarded many prizes of the tourism branch.

The organisational task of the post-mining tourism is based on preparing and managing the sightseeing and organising events in the sites and areas of former exploitation. The actions connected with organisation of different events in these places contribute to the promotion of a certain tourist destination greatly. For instance, in Poland, in Silesia, there is an annual event - Industriada - the Holiday of Industrial Monuments Route, the only festival of that kind in East-Central Europe, which in 2018 included: 2 days, 25 cities, 44 industrial monuments, over 500 attractions with a total number of 5741 events (Industriada, 2019). Geotourism events can be of different character and, with regard to the means of transport the geotourists use, one can divide them into: hike, bus, rail, plane and other trips. An interesting combination of car trips and hikes is the "one million of steps" ("Un millón de pasos") initiative, promoting the knowledge of post-mining sites in Linares-La Carolina mining region in Spain. Depending on a year, the event attracts from several to several hundred people following their guides and retracing the former lead ore mining on foot (Photo 11) or by an off-road car (Photo 12) depending on a type of the event.

The last of the mentioned tasks of the geotourism is the training task which, according to Miśkiewicz, should consist in educating and training of staff, e.g. guides (Miśkiewicz et al., 2007). Tourism use of a former mining facility can be combined

Photo 10. Exhibition of a former apartment in the passages after opal extraction in Coober Pedy, Australia

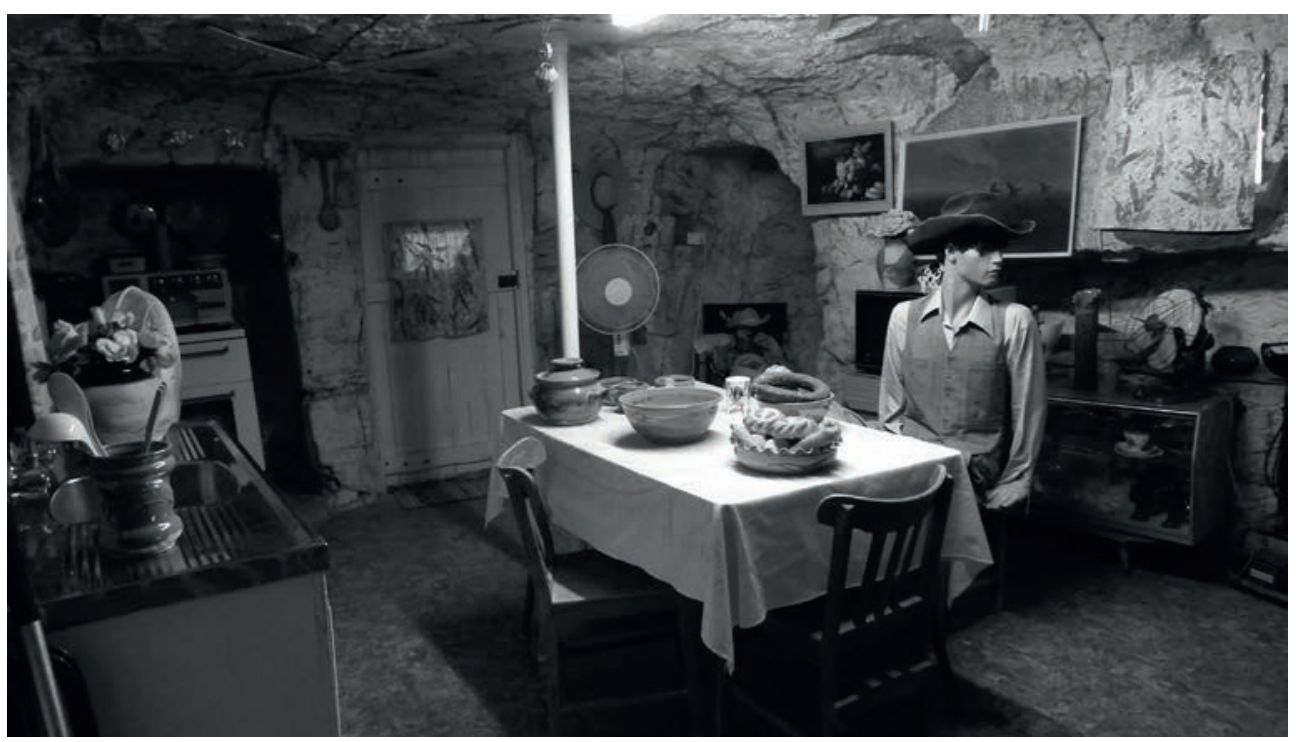

Source: A. Jagiełło 
Photo 11, 12. Participants of "Un millón de pasos" in 2012 in the field, surroundings of Linares, Spain
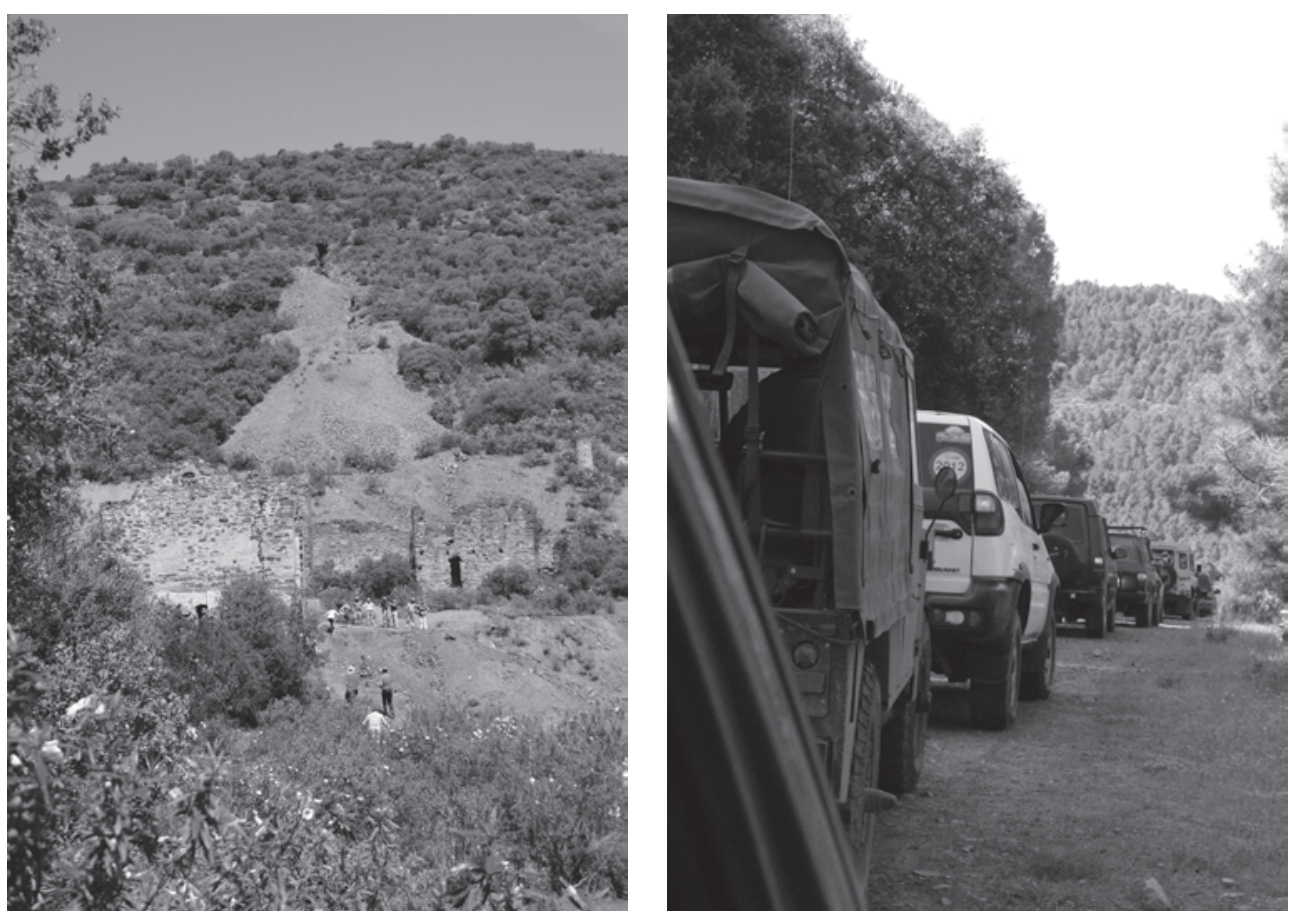

Source: M.W. Lorenc

with the training of mining staff, and the example here can be Municipal Museum and "Sztygarka" Training Mine in Dąbrowa Górnicza in Poland. The history of the Training Mine is connected with the history of museology and the Mining School called "Sztygarka" in Dąbrowa Górnicza. The building of the mine started in 1927, and practical classes for the students of mining schools took place there till 1994. Afterwards, a bad technical condition of the site resulted in the mine's liquidation. "Sztygarka" Municipal Museum (established in 1997) has taken care of the mine ever since. Well-preserved coal workings, galleries and machines were recognised as tourist attractions and after essential works had been performed, in 2010, the site of 650 metres length on two sightseeing levels was established. Apart from tourist functions, the Training Mine is still taken advantage of as the place of practical training, experiments and scientific research.

The way the guide handles tour groups often becomes an element of competitive advantage of the geotourism site. Therefore, in connection to geotourist guides' training, one should put a special emphasis on extensive qualifications of the tour guide and their personality joined with the skill of nurturing the visitors with enthusiasm for different geological qualities and those connected with the mining of a certain region.

\section{CONCLUSIONS}

The implementation of projects related to the use of former industrial and mining facilities brings direct and indirect benefits to the near and distant environment, as well as to the project beneficiaries. These benefits are often: 
- the benefits of reclamation related to the restoration and protection of natural balance,

- tourist benefits related to the restoration of post-mining areas to the natural environment in a condition suitable for recreational and tourist use, thus increasing their economic and social attractiveness,

- the benefits of preserving the historical value of mining facilities of a cognitive and didactic nature,

- other benefits, including those related to, for example, the elimination of threats to people and animals from post-mining facilities (Kobylańska, 2013).

During the execution of undertakings connected with creating geotourist products on the basis of geological sites and, especially, post-mining sites (areas), one should be focused on the tasks related to this kind of projects. These tasks are: documentation, educational (teaching), promoting, research and development, protection, designing, organisational and training tasks.

Paradoxically, the execution of promoting, designing, educational and organisational tasks through a geotourism undertaking, aims at the protecting of the site (which is the dominating aim) since the funds generated by a tourism activity may be used for further protection of the monument and the natural environment, as well as, for increasing social awareness in this scope. The promoting task includes all the actions connected with conveying knowledge of the site, including marketing and public relations activity. In general, promoting, training and designing tasks are of great importance for the successful geotourism project in relation to the interest of the visitors and the recognition of the site in a region.

One should also emphasise that all the tasks connected with a geotourism undertaking based on post-mining facilities and sites should constitute a cohesive whole including an economic, ecological, as well as social and cultural aspect, that is, they should fall in line with the concept of sustainable development in tourism.

\section{References}

Alexandrowicz, Z., Alexandrowicz, S.W. (2002). Geoturystyka a promocja dziedzictwa geologicznego [Geotourism and the promotion of geological heritage]. In: J. Partyka (ed.), Użytkowanie turystyczne parków narodowych [Tourism in national parks], Instytut Ochrony Przyrody PAN OPN, 91-97.

Baczyńska, E., Lorenc, M.W. (2012). Eden Project - the Cornwall Peninsula peculiarity. Geoturystyka - Geotourism, 1-2(28-29), 23-36.

Campos López, D., Dueñas Molina, J., Lorenc, M.W., Pérez Sánchez, A.A., Molina Molina, F., Susi Liébanas, J., Molina Vega, A., Villanueva Real, F. (2014). Heritage zone of the mining district Linares - La Carolina (Spain). Geotour \& IRSE 2014 Twin International Conference Proceedings, Miskolc, Hungary, 149-157.

Casagrandi, R., Rinaldi, S. (2002). A theoretical approach to tourism sustainability. Conservation Ecology, 6(1), 1-19.

Contreras Cortés, F., Dueñas Molina, J. (2010). La mineria y la metalurgia en el alto Guadalquivir: desde sus orígenes hasta nuestros días. Diputación Provincial de Jaén: Instituto de Estudios Giennenes, 422.

Czwartyńska, M. (2008). Obszary pogórnicze w postindustrialnej transformacji Górnego Śląska [The Mining Regions in the Post-Industrial Transformation of Upper Silesia]. Prace Komisji Geografii Przemysłu Polskiego Towarzystwa Geograficznego [Studies of the Industrial Geography Commission of the Polish Geographical Society], 10, 76-85. 
Davey, A. (1997). Concepts of significance in geoheritage assessment. In: R. Eberhard (ed.), Pattern and Process: Towards a Regional Approach for National Estate Assessment of Geodiversity, Technical Series No. 2, Australian Heritage Commission, Canberra, 15-19.

Hose, T.A. (2006). Geotourism and interpretation. In: R.K. Dowling, D. Newsome (eds,), Geotourism: sustainability, impacts and management, Elsevier/Heineman Publishers, Oxford, 221-242.

Industriada (2019, April 15). Industriada 2018 in numbers. Retrieved from: http://industriada. $\mathrm{pl} /$ aktualnosci/industriada-2018-w-liczbach/.

Jawecki, B., Lorenc, M.W., Mazurek, S. (2013). Kopalnie w krajobrazie powiatu strzelińskiego strzeliński granit w architekturze [Mines in the landscape of the Strzelin country - the Strzelin granite in architecture]. Architektura Krajobrazu [Landscape Architecture], 3(40), 108-123.

Kaspar, C. (1991). Die Tourismuslehre im Grundriss. Stuttgart, Bern: Verlag Paul Haupt.

Kobylańska, M. (2013). Koncepcja rozwoju produktu turystycznego na przykładzie ścieżki turystyczno-dydaktycznej „Śladami dawnego górnictwa kruszców” w gminie Mirsk [The concept of tourist product' development on example of tourist route "By the traces of the former ore mining" in the Mirsk Commune]. In: P.P. Zagożdżon, M. Madziarz (eds.), Dzieje górnictwa - element europejskiego dziedzictwa kultury. Tom V, Wrocław, 111-123.

Kobylańska, M. (2014). Model prognozowania efektywności przedsięwzięć geoturystycznych dla obiektów dziedzictwa górniczego [Prognostic model of effectiveness of geotouristic projects for mining heritage objects]. Dissertation. Wrocław: Biblioteka Główna Politechniki Wrocławskiej.

Miśkiewicz, K., Doktor, M., Słomka, T. (2007). Naukowe podstawy geoturystyki - zarys problematyki [Scientific bases of geotourism - outline of issues]. Geoturystyka - Geotourism, 4(11), 3-12.

Peréz Sánchez, A.A., Lorenc, M.W. (2008). The cultural landscape of the Linares - La Carolina mining district. Geoturystyka - Geotourism, 3(14), 13-24.

Różycki, P. (2010). Geoturystyka i turystyka industrialna na tle nowoczesnych form turystyki [Geotourism and industrial tourism as the modern forms of tourism]. Geoturystyka Geotourism, 3-4(22-23), 39-50.

Słomka, T., Kicińska-Świderska, A. (2004). Geoturystyka - podstawowe pojęcia [The basic concepts of geoturism]. Geoturystyka - Geotourism, 1, 5-7.

Tokarczyk-Dorociak, K., Lorenc, M.W., Jawecki, B., Zych-Głuszyńska, K. (2015). Basalt in Strzegom - Landscape changes of Szeroka Mountain. Zeitschrift der Deutschen Gesellschaft für Geowissenschaften (Z. Dt. Ges. Geowiss. German J. Geol.), 166(2), 195-203.

Zagożdżon, P.P., Zagożdżon, K.D. (2013). Udostępnione pogórnicze obiekty podziemne Dolnego Śląska jako zaplecze geoturystyczne [Underground tourist routes of Lower Silesia as geotourist objects]. Przegląd Geologiczny [Polish Geological Review], 61(1), 19-24.

Zeidler, K. (2009). Ochrona dziedzictwa kultury a turystyka, czyli w poszukiwaniu „złotego środka" [Cultural heritage protection and tourism - looking for the best solution]. Folia Turistica - Turystyka a prawo, Kraków, 20, 157-169.

Malwina Kobylańska, PhD, Eng, an assistant professor at the Geological Department at KGHM CUPRUM Ltd. Research and Development Centre, where she deals with technical and economic assessments of geological and mining projects for the purpose of evaluations for the investment involvement of KGHM Polska Miedź SA and monitoring of the global non-ferrous metals sector. For many years she has been involved in works related to the development of mining heritage objects for geotourist purposes. In 2015, she obtained a PhD from the Wrocław University of Technology in the Faculty of Geoengineering, Mining and Geology, specialising in environmental protection and utilisation of mining heritage.

ORCID: 0000-0002-4782-2875

\section{Address:}

KGHM CUPRUM Ltd. Research and Development Centre

Geological Department

ul. gen. Wł. Sikorskiego 2-8, 53-659 Wroclaw, Poland

e-mail: mkobylanska@cuprum.wroc.pl 
Marek W. Lorenc, DSc, a professor at the University of Environmental and Life Sciences in Wrocław, Poland, where, between 2008 and 2012, he has been vice-dean of the Faculty of Environmental Engineering and Geodesy, responsible for the Landscape Architecture field of study. He has more than 45 years of experience in geology and has published and lectured extensively in this field. His graduates in the period 2005-2018 include 3 doctors, 85 masters, 57 graduates and 22 engineers. He is a founding partner of a European Network of Mining Heritage Europamines Ltd., International Association of Geotourism, Scientific and Educational Association "Terra Minera", as well as an Honorary Member of the Spanish Association Colectivo Projecto Arrayanes. He is particularly interested in the mining heritage and problems of source-material for reconstruction of stone monuments.

ORCID: 0000-0002-2600-9033

\section{Address:}

Wrocław University of Environmental and Life Sciences The Faculty of Environmental Engineering and Geodesy Institute of Landscape Architecture ul. C.K. Norwida 25, 50-375 Wrocław, Poland

e-mail: marek.lorenc@upwr.edu.pl 